SEAN BRENNAN

\title{
LOCAL AUTHORITY LIABILITY FOR FLOODING: WHERE SHOULD LOSS FALL?
}

Submitted for the LLB (Honours) Degree

Faculty of Law

Victoria University of Wellington

2014 


\section{Table of Contents}

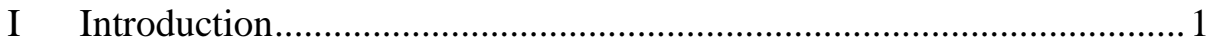

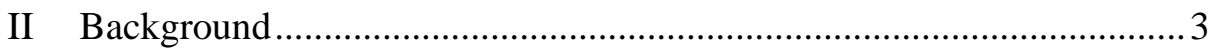

A Statutory Framework: Who Is Responsible for What? ........................ 3

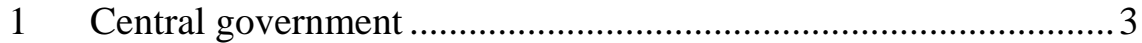

2 Regional and unitary councils ................................................... 4

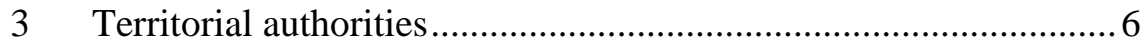

III Council Liability at Common Law ..................................................... 6

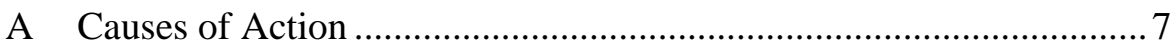

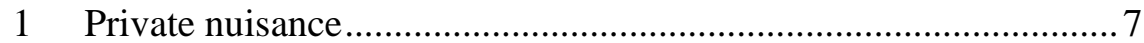

2 Negligence .............................................................................. 12

B Non-delegable Duties....................................................................15

1 "Inherently dangerous" activities ...............................................16

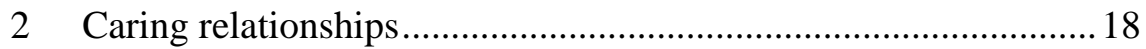

IV Should Councils be Liable? ................................................................ 20

A Homeowner and Local Authority Insurance .................................... 21

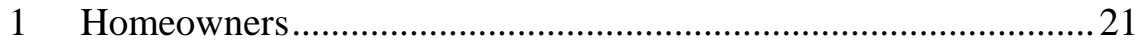

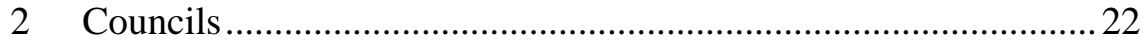

B Where Should Loss Fall? ...........................................................22

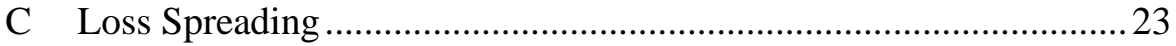

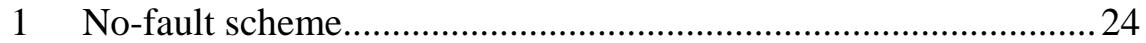

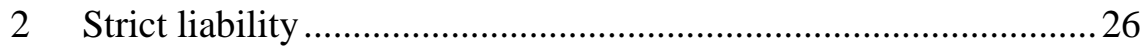

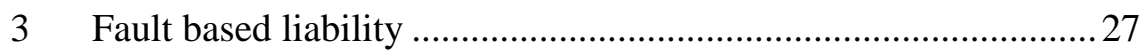

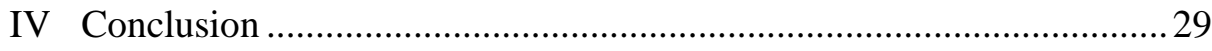

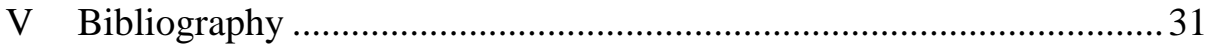




\begin{abstract}
Flooding is New Zealand's most frequent natural hazard the cost of which is outdone only by the recent Canterbury earthquakes. Local authorities are the bodies primarily tasked with protecting communities against flooding through a range of measures including physical works such as stopbanks. This essay explores the extent to which a local authority can be liable in tort where those physical works fail, causing damage. Direct liability and nondelegable duties are discussed, the latter addressing whether a local authority can nevertheless be liable having outsourced the construction of flood works to independent contractors. Additionally, whether local authorities should be liable for such damage or whether individual property owners ought to protect their own interests through insurance is discussed.Tthis essay recommends that property owners should purchase private insurance, but that local authorities should remain liable at least for their own negligence.
\end{abstract}

\title{
Keywords
}

Flooding; tort; local authority liability; non-delegable duty. 


\section{Introduction}

Flooding is New Zealand's most frequent natural hazard with climate change likely to increase both the intensity and frequency of major flooding events. ${ }^{1}$ On average a major flood occurs every eight months. ${ }^{2}$ Compounding the effects, most towns and cities are situated near rivers, increasing flooding's economic impact. ${ }^{3}$

In February 2004 extreme weather caused catastrophic flooding to homes, farms, and businesses in the Bay of Plenty, Manawatu-Wanganui, and Marlborough regions. The storms caused an estimated $\$ 400$ million in damage, \$112 million of which was fronted by insurance pay-outs and a further \$135 million in government aid for farmers. ${ }^{4}$ Approximately 2,600 farmers were affected, some unable to continue farming the land after returning. ${ }^{5}$ Pay-outs for flood loses between 1976 and 2004 are estimated at \$17 million and \$15 million per annum from insurance companies and the government respectively. ${ }^{6}$

More recently, the 2011 Canterbury earthquakes have caused rivers to become shallower and wider, making them more prone to flooding. ${ }^{7}$ Thus, many areas in Christchurch have experienced regular flooding as often as nine times in the space of just three years. ${ }^{8}$ As recently as July 2014,

$1 \quad$ See Mark Walton and others Economic impacts on New Zealand of climate change-related extreme events: Focus on freshwater floods (New Zealand Institute of Economic Research, July 2004).

2 Ministry for the Environment Meeting the Challenges of Future Flooding in New Zealand (Ministry for the Environment and the Flood Risk Management and River Control Review Steering Group, August 2008) at 1.

3 At v.

$4 \quad$ Eileen McSaveney “Floods: 2004 floods” (21 February 2013) Te Ara: The Encyclopedia of New Zealand <www.teara.govt.nz/en/floods> at 5.

$5 \quad$ At 5.

$6 \quad$ Eileen McSaveney “Floods: New Zealand’s number 1 hazard” (21 February 2013) Te Ara: The Encyclopedia of New Zealand <www.teara.govt.nz/en/floods> at 1 . University of Canterbury "Christchurch experiences more floods” (5 March 2014) University of Canterbury: Communications <http://www.comsdev.canterbury.ac.nz/rss/news/?feed=news\&articleId=1227> .

8 The Press "Widower suffers ninth flood since quakes" (29 April 2014) Stuff $<$ www.stuff.co.nz/national/9989139>. 
torrential rain falling over two weeks in Northland caused extensive flooding affecting businesses and residents. ${ }^{9}$

Numerous measures protect against flooding. These include weather forecasting, insurance, recovery plans, and the construction of physical works such as stopbanks and culverts. Responsibility for flood protection lies with local government: "The Government considers local risks to be a local responsibility”. ${ }^{10}$ Councils have extensive responsibility for managing flood risk. Flood protection measures are generally effective, but sometimes fail. Central government typically involves itself at the civil defence recovery stage only where necessary. In respect of physical works, money tends to be allocated by councils in respect of specific projects, rather than a single "flood protection" budget drawn from on an as-needs basis. For example, the Hutt City Council is currently planning to increase the height of the stop bank which protects the City from the Hutt River. This should be completed by 2022 with an allocated budget (including some other works) of $\$ 26$ million.

This essay explores the extent to which a local authority may be liable in tort for flood damage, addressing both direct liability and so called "nondelegable" duties for the work of contractors. An analysis of whether councils should be liable is undertaken with a brief evaluation of current practices of insuring against loss for both homeowners and local authorities. This essay concludes that, while local authorities can be liable for flooding in some circumstances, it is preferable for homeowners to purchase private insurance rather than extend local authority liability further than the current state of the law.

\footnotetext{
$9 \quad$ Lynley Bilby “Torrential rain causes slips and power cuts” The New Zealand Herald (online ed, Auckland, 20 July 2014).

10 National Civil Defence Emergency Management Plan Order 2005, Part 10, cl 89(2) promulgated under ss 39(1) and 45(b) of the Civil Defence Emergency Management Act 2002.
} 


\section{Background}

\section{A Statutory Framework: Who Is Responsible for What?}

Local government in New Zealand is made up of larger regional councils (RCs), and myriad smaller territorial authorities (TAs) servicing specific communities. Responsibility for managing flood risk is primarily vested in regional councils and territorial authorities - rather than central government - through a plethora of statutes, some over a century old. These statutes provide various tools. The two focused on in this essay are categorised as: ${ }^{11}$

(1) hazard controls - for example stopbanks, culverts, and their maintenance; ${ }^{12}$ and

(2) flood loss insurance. ${ }^{13}$

\section{$1 \quad$ Central government}

Central government plays a reduced role, focusing primarily on recovery. ${ }^{14}$ However, the Resource Management Act 1991 (RMA) requires the Minister for the Environment to ensure the Act is effectively implemented. ${ }^{15}$ The Ministry for the Environment is required to provide advice to the government, its agencies, and other public authorities on "the identification and likelihood of natural hazards and reduction of the effects of natural hazards". ${ }^{16}$ Despite this general duty to provide information no specific policy group or commission is tasked with guiding local government's approach to flooding.

Following 2005 RMA amendments the Minister has increased powers to address RMA issues. The Minister may investigate the performance of a local council, ${ }^{17}$ make recommendations, ${ }^{18}$ require the production of a

\footnotetext{
11 John McSweeny Overview of Flood Management Legislation in New Zealand (Ministry for the Environment, November 2006) at 12.

$12 \quad$ Local Government Act 2002; Soil Conservation and Rivers Control Act 1941; Rivers Board Act 1908; and Land Drainage Act 1908.

13 Earthquake Commission Act 1993.

14 National Civil Defence Emergency Management Plan Order 2005 Part 10, cl 89(2).

Resource Management Act 1991, s 24(f).

Environment Act 1986, s 31(c)(iv).

Resource Management Act 1991, s 27. Section 24A.
} 
"regional plan" to address issues, ${ }^{19}$ and in extreme circumstances appoint someone to take control of the functions, duties, and responsibilities of the authority. ${ }^{20}$

\section{$2 \quad$ Regional and unitary councils}

Following the Local Government Reorganisation Order 1989, 14 new RCs were formed (now 11). Within those regions there are 67 TAs compring 12 city councils, 54 district councils, and one Auckland Council. ${ }^{21}$ Six of these territories have the powers of both RCs and TAs, making them "unitary councils". Flood protection tasks are shared between RCs and TAs. However, commentary indicates that a lack of legislative clarity has made it difficult to determine to whom any given task falls. ${ }^{22}$ The boundaries for RCs are partly determined on the basis of water catchment areas, while TAs are based on community interests. Consequently, RCs have a greater degree of responsibility in respect of flood planning.

Under Schedule 10 of the Local Government Act 2002 (LGA), local authorities are required to produce "long-term plans”. Such a plan must be produced in respect of a range of a "group of activities", one such "group" being "flood protection and control works". ${ }^{23}$ This plan must detail inter alia how the plan is to be funded. ${ }^{24}$ Councils are also required to produce "regional policy statements” (RPSs). ${ }^{25}$ These seek to provide direction for resource management. A RPS must state "objectives, policies, and methods" to "avoid or mitigate natural hazards or any group of hazards". ${ }^{26}$ Under the RMA regional and district "plans" must "give effect" to the RPS. ${ }^{27}$ These "regional plans" may be created to address any major resource management issue.

Section 25A(1)(a)

Section 25.

Some TAs overlap with more than one of the 11 regions.

John McSweeny, above n 11, at 6.

Local Government Act 2002, Schedule 10, cl 2(2)(d).

Schedule 10, cl 3.

Resource Management Act 1991, ss 59-63.

Section 62(1)(i).

Sections 67(3)(c) and 75(3)(c). 
The RMA allows RCs to delegate or transfer a function, power, or duty to another "public authority" (including a local council). ${ }^{28}$ Authorities must continue to monitor the use of that delegated power. ${ }^{29}$

The Soil Conservation and Rivers Control Act 1941 (SCRCA) makes provision for "the prevention of damage by erosion" and to provide "protection of property from damage by floods." The Act creates catchment boards and provides them with the power to "minimise and prevent damage within its district by flood erosion", 30 and the power to "construct, reconstruct, alter, repair, and maintain” necessary works. ${ }^{31}$

The Public Works Act 1981 allows for the compulsory acquisition of private land for these works, ${ }^{32}$ for which compensation can be sought. ${ }^{33}$ The powers and responsibilities of "land drainage boards" constituted under the Local Government Act 1974 and Land Drainage Act 1908 are also vested in RCs. This includes the powers to construct and maintain drains and waterways. ${ }^{34}$

The 1989 Order provided that certain "functions, powers, and duties" were vested in RCs. For example, the Local Government (Bay of Plenty Region) Reorganisation Order 1989 states that: ${ }^{35}$

The functions, duties, and powers of the Bay of Plenty Regional Council shall be:

(d) The functions, duties, and powers of a catchment board ... under the Soil Conservation and Rivers Control Act ...

There are similar provisions for each region. Any reference to a catchment board in reality means the relevant RC.

Sections 33 and 34.

Section 35.

Soil Conservation and Rivers Control Act 1941, s 126(1).

Section 126(2).

Section 28.

Public Works Act 1981, Part 5.

Land Drainage Act 1908, s 17.

Local Government Reorganisation Order 1989, cl 16(d). 
3 Territorial authorities

TAs, like RCs, must ascertain policy and funding priorities in their longterm plans through which the annual plan gives effect. This can be achieved through "district plans", the purpose of which is to "assist territorial authorities to carry out their functions" to achieve the purposes of the RMA. ${ }^{36}$ At all times a district plan must be in place, prepared by the TA. ${ }^{37}$

TAs have responsibility for managing large networks of urban and land drainage infrastructure. ${ }^{38}$ A TA may require private land owners to provide drains, ${ }^{39}$ remove obstructions from drainage channels or watercourses, ${ }^{40}$ modify existing drains, ${ }^{41}$ and take private land for drainage purposes (with compensation payable). ${ }^{42}$

TAs, as the building consent authority for their district, have responsibilities under the Building Act 2004. ${ }^{43}$ A building consent may not be granted if the land is or is likely to be subject to flooding. ${ }^{44}$ A building consent may nevertheless be granted but the natural hazard risk will be recorded on the certificate of title. ${ }^{45}$ Other conditions may be placed on construction so as to comply with the Act and clause E1 (Surface Water) of the Building Code.

\section{Council Liability at Common Law}

Council work on flood protection is not always successful, and has led to flooding, damaging homes and businesses. An aggrieved party may seek legal redress, tort being an option. If so, a plaintiff must first determine the appropriate defendant. This will generally be either a RC or TA. An in-

Resource Management Act 1991, s 72.

Section 73.

Local Government Act 1974, ss 446-517.

Section 459.

Section 511.

Section 509.

Public Works Act 1981, Part 2.

Building Act 2004, s 212.

Section 71.

Sections 72-74. 
depth analysis of who is specifically responsible for what for the purposes of litigation is beyond the scope of this essay. ${ }^{46}$

The second consideration is the appropriate cause of action. This essay principally outlines the torts of private nuisance and negligence. Other claims may be available (such as public nuisance, ${ }^{47}$ or breach of statutory duty $^{48}$ ), but are not examined here. ${ }^{49}$

The third factor is to determine in what capacity the defendant may be held liable. The defendant may be directly liable for its wrongs, liable for the wrongs of its agents/employees (vicariously liable), ${ }^{50}$ or liable on the basis that it owed a non-delegable duty to the plaintiff. This essay amalgamates direct and vicarious liability as a council will likely accept liability in either case, but addresses non-delegable duties separately.

Councils are immune from liability in certain circumstances under both statute and common law. These immunities generally will not apply where there has been bad faith or gross negligence, ${ }^{51}$ or some other standard stipulated in the statute. However, there is no blanket immunity for councils in respect of all wrongs. This essay does not seek to discuss the current extent of local authority immunity except where relevant. ${ }^{52}$

\section{A Causes of Action}

\section{Private nuisance}

Broadly speaking, nuisance is an "unreasonable interference with a person's right to the use or enjoyment of an interest in land."53 While nuisance typically concerns on-going or intermittent interferences rather than isolated

\footnotetext{
46 See John McSweeny, above n 11, at 31-37 for a summary of provisions in flood related statutes.

47 Stephen Todd The Law of Torts in New Zealand (6th ed, Brookers, Wellington, 2013) at 560-569.

48 In the context of local authorities see Kenneth Palmer Local Authorities Law in New Zealand (Brookers, Wellington, 2012) at 153.

49 See John McSweeny, above n 11, at 31-37 for a summary of provisions in flood related statutes. See Kenneth Palmer, above n 48, at 119.

For example Civil Defence Emergency Management Act 2002, s 110.

For further details on council immunity see Kenneth Palmer, above n 48, at 157. Stephen Todd, above n 47, at 510.
} 
escapes this is not invariably true. ${ }^{54}$ Instances where isolated escapes have given rise to a claim in nuisance include a burst water main, ${ }^{55}$ a blocked drain causing a flood, ${ }^{56}$ and a gas explosion. ${ }^{57}$ Furthermore, the remedy of an injunction, not available under either Rylands $v$ Fletcher (discussed later) or negligence, may be more advantageous to a plaintiff than damages.

Private nuisance is bifurcated. There are two actionable species: interferences which result in "material injury to the property" and those causing "sensible personal discomfort" ${ }^{58}$ The former requires "material” or "substantial"59 damage, not merely "trivial”. 60 The latter requires a broad analysis of a range of factors including the nature of the locality. Flooding would engage both, but the focus here will be on "material injury to property”. Once the threshold of unreasonable interference with a relevant right is reached liability is strict.

Two questions need to be considered: firstly, because floods generally do not regularly recur in any given area, whether an isolated escape of this sort can constitute a nuisance, and secondly whether a council could be liable having allowed a nuisance to occur through, for example, having failed to unblock drains.

Sedleigh-Denfield engages both issues. ${ }^{61}$ The defendant's land sat on a slope above the plaintiff's. A drain with a culvert had been laid on the plaintiff's property by the local council without the plaintiff's authority. While the defendant had been periodically clearing out the culvert's mouth, at some stage heavy rainfall caused debris to block the pipe. Water then flooded the plaintiff's property. While the defendant had not created the nuisance, the issue was whether or not it could be liable for having continued it. The House of Lords found that it could. Lord Atkin stated that an occupier who

Hamilton v Papakura District Council [2000] 1 NZLR 265 (CA). Irvine \& Co Ltd v Dunedin City Corporation [1939] NZLR 741.

Pemberton v Bright [1960] 1 WLR 436 (CA).

Midwood \& Co Ltd v Mayor, Alderman and Citizens of Manchester [1905] 2 KB 597.

St Helen's Smelting v Tipping (1865) 11 HLC 642, 11 ER 1483 (HL) at 1486.

Davis v Lethbridge [1976] 1 NZLR 689 (SC) at 697.

Halsey v Esso Petroleum Co Ltd [1961] 1 WLR 683 (QB) at 691.

Sedleigh-Denfield v O’Callaghan [1940] AC 880, [1940] All ER 349 (HL). 
continues a nuisance with knowledge of its existence, having failed to take reasonable steps to end it, will be liable for harm caused by that nuisance. ${ }^{62}$ The fact that the escape was a one-off event was no barrier to recovery. There has been academic criticism of the blurring of intellectual distinctions between the rule in Rylands $v$ Fletcher (which typically concerns isolated escapes) and nuisance. ${ }^{63}$ However, several nuisance cases have succeeded on this basis, ${ }^{64}$ the doctrine now well established.

Pemberton $v$ Bright addresses the second issue as to whether council management of drainage works can result in actionable nuisances. ${ }^{65}$ The defendant council widened a bridge, and the culvert below it, by 10 metres. For three decades council workers regularly cleared it of debris. Following particularly heavy rainfall the culvert became blocked and nearby land flooded. The plaintiffs brought an action in nuisance. The Court held that, as the defendants had created a "potential nuisance" which became an actual nuisance when blocked, the council was liable. ${ }^{66}$

Further supporting isolated escapes from drains as "constituting a nuisance” Greenock Corporation v Caledonian Rail Co concerned a culvert in a stream. ${ }^{67}$ As part of a children's playground a concrete paddling pool and dam were built at the culvert's mouth. These works constituted a major obstruction to the water flow. During high rainfall the stream flooded and damaged the plaintiff's properties. Lord Findlay, in a passage followed by the House of Lords in Sedliegh-Denfield, ${ }^{68}$ said: ${ }^{69}$

It is the duty of any one who interferes with the course of a stream to see that the works which he substitutes for the channel provided by nature are

\footnotetext{
$62 \quad$ At 360.

63 Stephen Todd, above n 47, at 529.

64 For example Charing Cross Electricity Supply Co Ltd v Hydraulic Power Co [1914] 3 KB 772 (CA); Spicer v Smee [1946] 1 All ER 489 (KB); Hiap v Lee (Cheong Leong and Sons) Brickmakers Ltd v Weng Lok Mining Co Ltd [1974] 2 MLJ 1 (PC); Pemberton v Bright, above n 56; and Hill v Waimea County Council HC Nelson A8/84, 12 March 1987.

65 Pemberton v Bright, above n 56.

$66 \quad$ At 442.

$67 \quad$ Greenock Corporation v Caledonian Rail Co [1917] AC 556 (HL).

$68 \quad$ Sedleigh-Denfield v O’Callaghan, above n 61, at 353.

$69 \quad$ At 572 .
} 
adequate to carry off the water brought down even by extraordinary rainfall ...

Liability was appropriate because it was a direct result of the obstruction created by the defendants.

The New Zealand courts have followed the UK approach, although no plaintiff has had a notable success against a local authority in respect of flooding. In Atlas Properties several plaintiffs sued a council after a culvert was overwhelmed during a period of exceptional rainfall, the excess spilling out and flooding nearby properties and businesses. ${ }^{70}$ Nuisance was claimed but failed. Durie J held that in each of the cases discussed above a particular feature of the works resulted in the water's escape. In Greenock there was a dam and pool, and in Pemberton an unprotected culvert with a propensity to block existed. ${ }^{71}$ In Atlas, there had been no interference with the channel of water except for the construction of the culvert itself which, importantly, did not limit the natural flow of water.

The courts will thus hold councils liable for one-off escapes caused by blocked or restricted drains and culverts followisng heavy rain only where the work interferes with the natural flow of water. Furthermore, a council may inherit a nuisance if it continues it with knowledge that it has, or may cause harm, and fails to take reasonable steps to avoid that harm. This applies most appropriately to drains becoming congested.

Once an actionable nuisance has been established the usual remedy restraining the activity is an injunction. ${ }^{72}$ In the context of widespread flooding, which is irregular, damages will generally be appropriate. ${ }^{73}$ However, those residents suffering regular flooding in some areas of Christchurch since the 2011 earthquakes, for example, might prefer an injunction forcing the council to take measures to abate flooding. The terms

$70 \quad$ Atlas Properties Ltd v Kapiti Coast District Council HC Wellington CP172/00 19, December 2001. This case was appealed to the Court of Appeal on issues of causation in respect of negligence, the outcome unchanged (Atlas Properties Ltd $v$ Kapiti Coast District Council CA30/02, 20 June 2002).

71 At [47].

72 Subject to section 16A of the Judicature Act 1908.

73 For example, the loss of crops as a result of flooding can be recoverable as damages (Simpson v Attorney-General [1959] NZLR 546 (SC)). 
of an injunction vary and are tailored to the circumstances. An injunction need not require the defendant to cease an activity altogether, but only to bring it within a level which an ordinary person in the plaintiff's position could reasonably be expected to tolerate.

The rule in Rylands $v$ Fletcher,${ }^{74}$ generally regarded as a subset of private nuisance, ${ }^{75}$ may also be available. But, in the context of flooding, has been largely unsuccessful, ${ }^{76}$ with one anomalous exception. ${ }^{77}$ This is typically because flood works are not themselves extra-hazardous in the same way that, for example, explosives are. ${ }^{78}$

Even so, councils may be able to rely on section 148(1) of the SCRCA which provides:

No Board shall be liable for injury to any land or other property caused without negligence of the Board by the accidental overflowing of any watercourse, or by the sudden breaking of any bank, dam, sluice, or reservoir made or maintained by the Board.

Consequently, where a RC (or TA, if that power has been delegated pursuant to $\mathrm{s} 125$ of the Act $)^{79}$ can show that for the purposes of the relevant works it was operating as a "catchment board" negligence must be shown before liability will follow. Claims in Rylands $v$ Fletcher and nuisance, being strict liability, will be excluded unless the physical work fall outside those enumerated in the provision. For example, where the works are principally for a different purpose from those set out in section 10 (a bridge or road is constructed, for example) then the work may instead fall within the exercise of powers under the LGAs. ${ }^{80}$

\footnotetext{
$74 \quad$ Rylands $v$ Fletcher (1868) LR 3 HL 330.

75 Cambridge Water Co Ltd v Eastern Counties Leather plc [1994] 2 AC 264 (HL) at 304 per Lord Goff.

$76 \quad$ Atlas Properties Ltd v Kapiti Coast District Council, above n 70; and Easton Agriculture Ltd v Manawatu-Wanganui Regional Council [2012] 1 NZLR 120 (HC).

$77 \quad$ Green v Hamilton City Council DC Hamilton NP 921/98, 2 March 2000.

78 See Easton Agriculture Ltd v Manawatu-Wanganui Regional Council, above n 76, at [118]. See generally Kenneth Palmer, above n 48, at 122.

79 For example Atlas Properties Ltd v Kapiti Coast District Council, above n 70, at [17].

$80 \quad$ Local Government Act 2002 and Local Government Act 1974.
} 
Section 148(1) "has the statutory consequence of effectively displacing other forms of liability, apart from negligence". ${ }^{81}$ However, it is not clear whether the section rules out a claim in nuisance where the remedy sought is an injunction rather than damages. The provision has been narrowly interpreted. In Atlas Properties, discussed above, the stopbank was intentionally built so that if the culvert was overwhelmed, the excess water would flow over the bank, albeit then flooding the plaintiff's property. Curiously, Durie J held that there was no "accidental overflow", the overflow being the intentional result of a floodplan, s 148(1) therefore not applying. ${ }^{82}$ Nevertheless, even if the section does apply, an action in negligence may be brought.

\section{$2 \quad$ Negligence}

The tort of negligence operates where a defendant has been careless in some legally relevant way. In particular, it has four main elements: (1) the defendant owed the plaintiff a 'duty of care'; (2) the defendant breached that duty of care; (3) the harm suffered by the plaintiff was caused by the defendant's breach; and (4) the harm caused was not too 'remote' from the breach. ${ }^{83}$

\section{(a) Duty of care}

Whether a duty of care is owed is assessed, firstly, on whether the relationship between the parties is sufficiently "proximate", then analysing "policy" arguments, often external to the parties, either militating against or enforcing a duty. This part addresses arguments of proximity. The policy of council liability will be addressed later. However, when seeking to impose a private duty against a public authority exercising its public functions, the courts have been hesitant to recognise a duty. This issue is commonly referred to as "justiciability" and is relevant to both "proximity" and “policy”.

$81 \quad$ Easton Agriculture Ltd v Manawatu-Wanganui Regional Council, above n 76, at [106]. Note that the case was appealed, but substantive issues discussed here were not raised (Easton Agriculture Ltd v Manawatu-Wanganui Regional Council [2013] NZCA 79 (26 March 2013).

$82 \quad$ Atlas Properties Ltd v Kapiti Coast District Council, above n 70, at [20].

83 Stephen Todd, above n 47, at 147. 
It is highly unlikely that issues of justiciability will arise where a local authority chooses to undertake flood protections and then carries them out without reasonable care. For example, if a council decides to provide stopbanks to protect against a 1 in 50 year flood, and a 1 in 100 year flood occurs, damaging the plaintiff's property, the claim would likely not proceed. The plaintiff would have to allege that the council was negligent in its decision to protect only against a lesser flood. On the other hand, if the same decision was made and works were carried out carelessly and a 1 in 25 year flood occurred damaging the plaintiff's property because the stopbank was not built with due care, the harm results from the operation of the decision rather than the decision itself. Consequently a claim will appropriately lie against the authority. This is commonly referred to as the "operational" "policy" distinction, ${ }^{84}$ although it is more appropriately a spectrum than a dichotomy. ${ }^{85}$ There are two New Zealand cases which exemplify the courts' approach to this type of duty in respect of flooding.

In Easton Agriculture the Council had levied extensive rates to fund a flood management programme, undertaking monitoring and maintenance of the works. ${ }^{86}$ Kós $\mathrm{J}$ found that the parties were sufficiently proximate. Firstly, the statutory purpose of s 148 (see above) indicates that councils "should be liable if they are negligent in the construction or maintenance of stopbanks". ${ }^{87}$ Secondly, the council specifically undertook the monitoring and maintenance of stopbanks, paid for through significant rates. ${ }^{88}$ It was also "wholly foreseeable" that a failure to carefully check the stopbank would result in the damage that it did. ${ }^{89}$ Finally harm resulting from an omission to maintain, rather than a positive act of negligence, did not prohibit a duty being owed..$^{90}$

$84 \quad$ Anns v Merton London Borough Council [1978] AC 728 (HL).

85 See generally Kenneth Palmer, above n 48, at 142 and Andrew Butler, Dean Knight and Geoff McLay "Liability of Local Authorities" (paper presented to the New Zealand Law Society, Wellington, June 2005) at 45-51.

$86 \quad$ Easton Agriculture Ltd v Manawatu-Wanganui Regional Council, above n 76.

87 At [132].

88 At [133].

89 At [146].

$90 \quad$ At [139], citing Goldman v Hargrave [1967] 1 AC 645 (PC); Landon v Rutherford [1951] NZLR 975 (HC); and Leaky v National Trust [1980] QB 485 (CA). 
This can be contrasted with the approach taken in Atlas Properties where it was found that s 148(1) did not apply, and therefore different considerations arose. There, Durie J stated that the Council must have been assumed to have taken into consideration "the suitability of the land ... having regard to the prospect of inundation."91 Before granting an application for subdivision, the Council was required to consider the risk of inundation. ${ }^{92}$ The Council granted the subdivision requiring earthworks to be undertaken. Later on permits for construction on the land were granted, again, requiring the Council to be satisfied of the land's security from flooding. On these bases the exercise of statutory powers made the parties sufficiently proximate.

These two cases illustrate different ways of finding that the relevant councils owed a duty of care. In summary, many considerations lead to a council owing a duty. Firstly, most significant building work requires approval by a council after having considered the land's susceptibility to flooding. Secondly, councils levy rates from the public in order to fund flood protection measure. Thirdly, it is reasonably foreseeable that, if a council carelessly undertakes its statutory obligations to protect against flooding, then damage by flooding may occur. These cases illustrate that the courts are willing to impose a duty, and overcome issues of justiciability. ${ }^{93}$ Yet, whether a duty is owed in any given case will depend on its facts.

(b) Breach, causation, and remoteness

As these enquiries tend to be factual analyses rather than legal, an attempt to canvass the multitude of scenarios in which a local authority may have breached a duty in any given situation is unnecessary. However, the greatest difficulty plaintiffs appear to have in negligence claims of this nature is proving that the authority's breach of its duty caused the damage. ${ }^{94}$ It is

Atlas Properties Ltd v Kapiti Coast District Council, above n 70, at [47].

Now the Resource Management Act 1991, s 106.

For a longer discussion on the source of the duty of care owed by a local authority, see Butler, Knight and McLay, above n 85, at 39-42.

$94 \quad$ Both Easton Agriculture Ltd v Manawatu-Regional Council above n 76, and Atlas Properties Ltd v Kapiti Coast District Council above n 70 were upheld on appeal as to the Judges' findings that there was no causation (Easton Agriculture Ltd v Manawatu-Wanganui Regional Council [2013] NZCA 79 (26 March 2013) and 
typically argued that, even if the authority had been careful, the same damage by flooding would have occurred. ${ }^{95}$

\section{B Non-delegable Duties}

As discussed, local authorities can be liable for flooding damage for their own torts and those of their employees (through vicarious liability). However, it is less clear whether local authorities owe a so-called "nondelegable duty of care", a developing area of the law. Despite the phraseology "duty of care”, typically associated with the tort of negligence, the doctrine applies more broadly. Similarly to vicarious liability, nondelegable duties seek to impose liability for another's torts, not just negligence.

Where a wrong is committed by an employee vicarious liability will typically be the appropriate path to find the employer liable. ${ }^{96}$ However, where a defendant has contracted out for work to be done, they are usually entitled to leave that contractor unsupervised. ${ }^{97}$ This is where the courts distinguish between a contract of service (an employee) and a contract for services (a contractor). ${ }^{98}$

The doctrine of non-delegable duties tends to operate where the defendant is in a position of control, the defendant engages another to do work, that work poses some "special danger", and the plaintiff is particularly vulnerable or is dependent on the defendant. ${ }^{99}$ Specifically in the context of local authorities the LGA stipulates that: ${ }^{100}$

... no delegation relieves the local authority ... of the liability or legal responsibility to perform or ensure performance of any function or duty.

Atlas Properties Ltd v Kapiti Coast District Council CA30/02, 20 June 2002 respectively).

$95 \quad$ Atlas Properties Ltd v Kapiti Coast District Council, above n 70, at [7]. See also Powrie v Nelson City Corporation p1976] 2 NZLR 247; Gazley v Lower Hutt City Council HC Wellington CP 460-90, 1 April and more generally Butler, Knight and McLay, above n 85, at 130-132.

96 See generally Stephen Todd, above n 47, at 1143-1189.

97 Cashfield House Ltd v David \& Heather Sinclair Ltd [1995] 1 NZLR 452 (HC) at 466.

$98 \quad$ Woodland v Swimming Teacher Association [2013] UKSC 66, [2014] AC 537 at [15].

$99 \quad$ Stephen Todd, above n 47, at 413.

$100 \quad$ Local Government Act 2002, Schedule 7, cl 32(7), 
1 "Inherently dangerous" activities

The orthodox position has been modified by a recent UK Supreme Court decision, Woodland $v$ Swimming Teacher Association. ${ }^{101}$ There, the appellant was a student of a local school which provided swimming lessons to students. The school sought an independent contractor to undertake these lessons. At some stage during the lesson, the appellant lost consciousness under water, was resuscitated, but suffered a serious hypoxic brain injury. It was accepted that the school could not be vicariously liable as the swimming instructors were "truly independent contractors". ${ }^{102}$ The appellant sought to recover against the school on the basis that it owed her a non-delegable duty of care. The school countered by claiming that, as the instruction was given by an independent contractor, the contractor alone remained liable, not the school.

Lord Sumption, delivering the judgment of the majority, ${ }^{103}$ noted two categories of non-delegable duty. ${ }^{104}$ The first of these categories (although not relevant to that case), ${ }^{105}$ endorsed in New Zealand, ${ }^{106}$ operates where the defendant employs a contractor to perform a function which is inherently dangerous. This category is typically reserved for "especially hazardous activities", itself split into the "highway" cases, and the more general "extra hazardous" cases. ${ }^{107}$ While some floodworks also constitute roads (culverts under bridges, for example) the highway cases will not be canvassed here as they occupy a very specific place within the "especially hazardous" category. ${ }^{108}$ The more general "extra hazardous" category will be the focus of this part.

\footnotetext{
$101 \quad$ Woodland v Swimming Teacher Association, above n 98.

102 At [3].

103 With whom Lady Hale agreed but wrote a separate judgment.

104 At [6].

105 At [6].

$106 \quad$ Stephen Todd, above $\mathrm{n}$ 47, at 1179.

107 Honeywill and Stein Ltd v Larkin Brothers (London's Commercial Photographers Ltd) [1934] 1 KB 191 (CA).

108 For a comprehensive discussion of the "highway" cases see Salsbury $v$ Woodland [1970] 1 QB 324 (CA), and in the New Zealand context McLellan v New Zealand Roads Ltd [1927] NZLR 172 (SC); Meurs v Taieri County [1954] NZLR 1080.
} 
In the Australian decision Burnie Port Authority $v$ General Jones, ${ }^{109}$ the defendant hired contractors to carry out welding work, aware that highly inflammable substances were stored where the work was to be carried out. A fire eventuated, spreading to a neighbour. The defendant could not escape liability, having undertaken an exceptionally dangerous activity, and therefore owed a non-delegable duty.

In reaching this conclusion, the Court in Burnie drew on an older New Zealand case, Black $v$ Christchurch Finance. ${ }^{110}$ There, a contractor negligently lit a fire to burn off bush on the defendant's land, contrary to the terms of the contract. The fire spread to the plaintiff's land. The defendant was liable on the basis that the activity was so dangerous that the defendant had a duty to "use all reasonable precautions". The scope of non-delegable duties was further extended in New Zealand in Mt Albert Borough Council v Johnson. ${ }^{111}$ A development company had built houses on subdivided land. The company was held to be under a non-delegable duty to ensure that proper care and skill was exercised in the houses' construction. The Court provided little guidance as to why this was so other than that the buildings were intended to "house people for many years". ${ }^{112}$

Many of the cases which have held non-delegable duties to exist have featured the statutory empowerment of a body to undertake a task in circumstances where a plaintiff could not be reasonably expected to undertake that duty or function themselves. ${ }^{113}$ Therefore, because local authorities are empowered by statute to undertake the construction of flood works, a task most people cannot conduct themselves, a non-delegable duty may be appropriate.

However, on balance it cannot be convincingly argued that the construction of flood works falls within this "extra hazardous" category. Flood works (once constructed) do not possess the same kind of dangers as explosives or

\footnotetext{
109 Burnie Port Authority v General Jones Pty Ltd (1994) 179 CLR 520 (HCA).

$110 \quad$ Black $v$ Christchurch Finance Co Ltd [1894] AC 48, (1893) NZPCC 448.

$111 \quad$ Mt Albert Borough Council v Johnson [1979] 2 NZLR 234 (CA).

112 At 240.

113 For example foster care in $S$ v Attorney-General [2003] NZCA 149, [2003] 3

NZLR 450.
} 
inflammable materials. ${ }^{114}$ In the context of whether stopbanks are "nonnatural” under Rylands $v$ Fletcher, it has been acknowledged that stopbanks and other flood works, do not themselves engage hazards but instead seek to minimise a risk that natural causes have already created. ${ }^{115}$ Consequently, it would be counter-intuitive to consider the works as sufficiently hazardous in themselves such that a non-delegable duty should be owed. While Mt Albert leans in favour of such a duty, flood works also being intended to exist for some time to protect people, the reasoning is not sustainable past Woodland and Burnie. Mt Albert should therefore no longer be followed in New Zealand.

\section{$2 \quad$ Caring relationships}

The second category of duty noted by Lord Sumption in Woodland relevant to that case - typically concerns caring relationships and has three principal features. Firstly, the duty arises from "an antecedent relationship" between the parties. Secondly, the duty is a positive one to protect the plaintiff and not merely to avoid causing harm. Thirdly, the duty is "by virtue of that relationship personal to the defendant."116

Liability on the basis of a non-delegable duty of this sort has been held appropriate in a series of clearly delineated areas including employer employee relationships, ${ }^{117}$ hospital care, ${ }^{118}$ and the care of children in schools. ${ }^{119}$ These cases feature a familiar reiteration of the rubrics of control, assumption of responsibility, and vulnerability importing a degree

\footnotetext{
114 For example, The Greater Wellington Regional Council described stopbank as "continuous mounds of earth built near rivers" (Greater Wellington Regional Council "Stopbanks and flood ways” (2014) Greater Wellington Regional Council $<$ www.gw.govt.nz/Stopbanks-and-flood-ways>).

115 Easton Agriculture Ltd v Manawatu-Wanganui Regional Council, above n 76, at [118].

$116 \quad$ Woodland v Swimming Teacher Association, above n 98, at [7].

$117 \quad$ Wilsons \& Clyde Coal Co Ltd v English [1938] AC 57 (HL); McDermid v Nash Dredging and Reclamation Co Ltd [1987] AC 906 (HL); and Kondis v State Transport Authority (1984) 154 CLR 672 (HCA) at 29-33.

118 Gold v Essex County Council [1942] 2 KB 293; Cassidy v Ministry of Health [1951] 2 KB 343; and X (Minors) v Bedfordshire County Council [1995] 2 AC 633 (HL) at 740. 
of risk associated with the operation. ${ }^{120}$ Control under this category of nondelegable duty means control over the claimant for the purpose of performing a function rather than control over the physical environment in which the harm occurs. ${ }^{121}$

Lord Sumption then stated five general factors, three of which can be applied to flooding. ${ }^{122}$ Firstly, the plaintiff is "especially vulnerable" to the defendant. Secondly, there is a relationship of actual custody or care from which an assumption of responsibility can be imputed to the defendant. Thirdly, the plaintiff has no control over how the obligation is performed.

There are some similarities between this type of duty and flooding protection. However, these do not appear to be sufficient to bring the council within the ambit of the doctrine for the purpose of protecting the community at large from flooding. Factors pointing in favour of there being such a duty include the relevant statutory empowerment to undertake flood protection, and provisions in the LGA which state that an authority will remain liable even in the event of delegation. ${ }^{123}$ Additionally, protection from floods is difficult, and for individuals to undertake, often impossible. Consequently, a local authority is far better placed to address the issue. Furthermore, many populated areas of New Zealand are at a high risk of being flooded. Consequently, there may be said to be a certain 'risk' around this type of work in respect of which it is more appropriate to impose a nondelegable duty.

However, many factors run contrary to such a duty. Firstly, while many who live in flood prone areas may be vulnerable to flooding, they are not "especially vulnerable" in the same sense that a prisoner, patient, or child is vulnerable to risk created by the circumstance of their care arrangements. Flood works do not engage hazards but instead mitigate them. Secondly, the harm under this type of duty has always been in respect of personal injury

\footnotetext{
$120 \quad$ For a clear example see New South Wales v Lepore (2003) 212 CLR 511 (HCA). The case concerned a sexual abuse at a school.

$121 \quad W o o d l a n d v$ Swimming Teacher Association, above n 98, at [24]. Compare A (Child) v Ministry of Defence [2005] QB 183.

122 At [23].

123 Local Government Act 2002, Schedule 7, cl 32(7).
} 
rather than property damage. ${ }^{124}$ Thirdly, there is no "antecedent relationship" such that the council has actual custody over the properties of general homeowners in the same way that a school has custody over children in its care. Consequently, the necessary assumption of a positive duty to protect the plaintiff's property cannot be imputed. ${ }^{125}$ Fourthly, a plaintiff, through community consultation, may have a say in how the council goes about performing its flood protection obligations. As Easton Agriculture illustrates, the extraction of rates can bring with it public consultation.

In conclusion, the differences between the line of cases under this category of non-delegable duty and the nature of flood damage (in particular, the focus on the person rather than property) may be an insurmountable hurdle despite legislative indications to the contrary. ${ }^{126}$ Consequently, even if the New Zealand courts adopt Woodland, councils under neither category are likely to owe a non-delegable duty to members of the general public for failed flood works.

\section{Should Councils be Liable?}

Floods will continue to occur. These floods will cause damage and someone will pay for that damage. While, in the right circumstances, a local authority can be liable for flood damage, is it appropriate that they should? In reality, are they covered by other policies such as insurance? Should liability be strict, or merely fault based? This discussion involves three key players: residents and businesses who suffer harm, councils, and the insurance industry. The 'big picture' issue is whether individual members of the community are to bear the cost themselves (individual liability), or whether councils should protect individuals by distributing that loss through rates (communal/council liability). The author argues that an amalgam of the two models is preferable, while recognising that the distinction may be artificial

\footnotetext{
$124 \quad$ While personal injury may not be an impossible result, property is the focus in New Zealand.

125 However, this may be different where a council has condemned a property until a problem (such as flooding) has been remedied, creating a pseudo-physical custody of the property. For example, the red zoning of large areas of property in Christchurch following the Canterbury earthquakes may suffice. Local Government Act 2002, Schedule 7, cl 32(7).
} 
in light of insurance practices and the potentially inhibitive cost of litigation. An analysis of loss spreading will inevitably require an elucidation of some economic concepts. A brief discussion about current insurance practices is also necessary. Policy arguments below may also be applicable as to whether a duty of care is "fair, just and reasonable"127 for the purposes of a negligence claim.

\section{A Homeowner and Local Authority Insurance}

\section{$1 \quad$ Homeowners}

The primary means of protecting homes and their contents is through private insurance policies. Few home insurance policies exclude flood damage. ${ }^{128}$ The Earthquake Commission (EQC), a Crown entity, also provides national insurance called EQCover. EQCover insures residential buildings against natural disasters including storms and flooding. EQCover is paid from the Natural Disaster Fund (the Fund) under the Earthquake Commission Act 1993.

EQCover is automatic for those who have private insurance policies for their home and/or contents that includes fire damage. Cover for "storm or flood" damage is more limited than other natural disasters. Claims may be made only in respect of "residential land", ${ }^{129}$ not contents.

A Levy included in insurance premiums paid by customers is paid to EQC. EQCover pays a maximum of $\$ 100,000$ for damage to "residential buildings”, the balance paid by insurance companies under the customer's policy. An insurance company could seek to recover the balance against a local authority for damage resulting from an authority’s negligent safeguard. The Insurance Council of New Zealand is unaware if a claim has been

\footnotetext{
127 Couch v Attorney-General [2008] NZSC 45, [2008] 3 NZLR 725 [No 1] at 52.

128 Email from Terry Jordan (Operations Manager for the Insurance Council of New Zealand) to Sean Brennan regarding the percentage of homeowners with insurance cover for flooding (30 June 2014). However, those buildings subject to a section 74 notice under the Building Act 1991 are unlikely to be covered. 
brought against a local council for flooding. ${ }^{130}$ However, insurers potentially can recover costs for loses resulting from the negligence of others.

\section{$2 \quad$ Councils}

Councils insure their own assets against flood damage in a range of ways, for example through the Local Authority Protection Programme Disaster Fund ${ }^{131}$ and through private insurance policies. Liability insurance may be purchased in respect of damage caused by the council to private individuals.

\section{B Where Should Loss Fall?}

As discussed above, this essay addresses individual and communal/council liability. A system of individual liability would require that councils either be completely immune from actions or be liable only in limited circumstances, for example negligence. ${ }^{132}$ Both options would require legislative action. Individuals would be expected to absorb the loss themselves, a majority of whom will have home insurance. As a general rule insurance companies charge more over time in accumulative premiums than the value of what they pay out, otherwise there would be no market for insurance (leaving aside reinsurance). Consequently the community as a whole will pay more to insurance companies than the total value of losses from flooding, except in extreme events where insurers cannot afford to pay out all claims. ${ }^{133}$ Despite this, people are generally risk averse. When faced with the choice between a small certain loss and a higher but uncertain loss of equal value, people prefer the certain outcome. ${ }^{134}$

While most homeowners do have home insurance which covers flood damage (further protected by EQCover) and can therefore pass that loss on to insurance companies, those who do not have insurance may be greatly

\footnotetext{
130 Interview with ICNZ representative, Senior Representative (Sean Brennan, The Insurance Industry and Flooding, 8 August 2014).

131 LAPP “About LAPP: Background \& History” (2013) LAPP: Local Authority Protection Programme <www.lappfund.co.nz>.

$132 \quad$ As reflected in s 148(1) of the Soil Conservation and Rivers Control Act 1941.

133 This is exemplified by the cost to the LAPP fund of the Canterbury earthquakes. See The Press “Disputes over insurance payout” (8 May 2014) Stuff $<$ www.stuff.co.nz/national/10020889>.

134 Michael Faure Tort Law and Economics (Edward Elgar, Cheltenham (UK), 2009) vol 1 at 377 .
} 
burdened. The average homeowner's most valuable asset, their home and land, may be prohibitively expensive to rebuild. This is a major downfall of individual liability. Additionally, if councils were never liable for damage, they may be less motivated to carefully undertake flood protection.

Individual liability is nevertheless advantageous for a number of reasons, apparent when examining the council liability model. If councils are to be liable they will pass that loss back to the public at large through rates. The income from rates can then be applied in one of two ways. A general fund may be created into which those rates are paid and from which money can be drawn to settle claims against the council. Alternatively it could be used to purchase liability insurance. Regardless of how the money is used, this essay refers to both types of scheme, interchangeably, as a 'rates based' insurance scheme. Therefore where councils have this protection they will be largely unaffected. Nevertheless, if councils were to be liable the price of home insurance in respect of flooding should decrease as insurance companies would be able to pursue claims against councils more readily.

However, home and business owners with private insurance will lose out. They will not only be paying insurance premiums privately in excess of the value of the overall loss, but will also be funding the council's insurance. These rates are unlikely to be popular among homeowners who already have insurance, infringing on a homeowner's autonomy to insure how they wish, if at all. In conclusion, the individual liability model would be economically efficient, but may be unduly harsh on those who cannot afford to insure their homes.

\section{Loss Spreading}

Nevertheless, should the council liability model be adopted, a system of loss distribution would have to exist. While there are three specific rating systems, these are beyond the scope of this essay. ${ }^{135}$ Instead, three different forms of loss spreading will be discussed: a no-fault ACC-type scheme (not dissimilar to, but going further than EQCover), strict liability, and fault

135 See Kenneth Palmer, above n 48, at 481 for a comprehensive discussion on the various rating systems. 
based liability. Realistically, the current system is an amalgam of all three. As shown above, local authorities can be liable for their torts, including the strict liability nuisance and Rylands torts, with EQCover operating where the owner has the necessary insurance. However, in some circumstances (for example, an authority which falls within s 148(1) of the SACRA) then an authority may only be liable in respect of its negligence. While total immunity from civil actions in this context can be viewed as a type of loss spreading, this would equate to the individual liability model above and is not discussed here.

\section{$1 \quad$ No-fault scheme}

The revolutionary 'Woodhouse Report' ${ }^{\text {'36 }}$ paved the way for the no fault ACC scheme in respect of personal injury: "Injury, not Cause, is the Issue". ${ }^{137}$ The government would cover the cost of personal injuries and proceedings for personal injury were barred. ${ }^{138}$ The report states five fundamental principles under which the scheme is to operate: ${ }^{139}$ community responsibility, comprehensive entitlement, complete rehabilitation, "real compensation”, and administrative efficiency.

This scheme bears some similarities with EQCover which involves the government remedying damage caused by natural disasters without being concerned whether anyone was at fault for that loss. ${ }^{140}$ This could be seen as a property-based parallel to "rehabilitation" under ACC.

However, the differences are significant. EQCover is not indiscriminate. Only those who have taken out the necessary insurance will receive EQCover pay-outs, unlike ACC which pays out irrespective of insurance. Furthermore, EQCover will only extend up to a certain dollar value, as

\footnotetext{
136 New Zealand Royal Commission of Enquiry into Compensation for Personal Injury Compensation for Personal Injury in New Zealand: Report of the Royal Commission of Inquiry (Government Printer, Wellington, 1967) (The Woodhouse Report).

137 At [4].

138 Accident Compensation Act 2001, s 317. However, s 319 still permits actions for exemplary damages.

139 The Woodhouse Report, above n 136, at [55]-[63].

140 Damage by natural disaster in most circumstances will not be anyone's 'fault'. However, this essay has demonstrated that, for example, local authorities can still be liable for such damage in some circumstances.
} 
discussed above. Consequently, neither the third nor fourth Woodhouse principles could be said to be met in every pay-out. While the limited coverage will be sufficient in some circumstances, in others it may be grossly inadequate.

Should EQCover be extended to occupy a position analogous to ACC? The answer must be 'no', unless the source of funding is significantly altered. ACC pays those who suffer injuries, and ACC is in turn funded through a variety of levies. Generally people are levied irrespective of risk.

Because EQCover is funded through a portion of insurance premiums paid by insurance companies, in order to function like ACC EQC would have to draw costs from the homeowners more directly. Alternatively, if EQC required payments from local authorities based on the value of property within their geographical ambit then the authority could then charge rates from homeowners who would benefit from that protection.

Additionally, it may also be important to consider the relevant risk to a homeowner of flooding, although this is less emphasised in the ACC scheme. Those living in flood prone areas, being more likely to benefit from rates-based insurance, ought to pay more than those less likely to suffer flooding damage. Indeed, as was the case in Easton Agriculture, the stopbank was built using funds specifically levied from those at risk of inundation. Rate gathering like this would reflect the pragmatic egalitarianism of the Woodhouse Report, but depart somewhat from ACC's source of funding. ${ }^{141}$ A risk based assessment may be more favourably viewed by those at a lesser risk of flooding. Realistically these rates would constitute a compensation scheme rather than a liability model.

A fundamental presupposition of the ACC scheme is that there was a significant problem with the previous system: one's ability to recover was a "lottery" based upon the few occasions where that harm was caused through an actionable tort or where compensation was available under the piecemeal

141 See also Tsachi Keren-Paz Torts, Egalitarianism and Distribute Justice (Ashgate, Burlington (USA), 2007) at 7. 
compensatory legislation of the time. ${ }^{142}$ This factor along with the Woodhouse Report principles indicated a clear public good in having the public at large foot the bill. Does flooding fit this mould, though? Clearly flooding can cripple communities financially. However, to say that there is a significant problem with the current approach necessitating such significant reform would be ambitious. Whether a person is covered is less a lottery and more a calculated decision: "do I buy insurance and receive the associated benefit from EQCover, or do I save those premiums hoping that I can cover any cost I may have, and rely on possibly bringing a claim against an authority?” If a no-fault scheme were adopted, as above, those who do buy insurance may be required to indirectly foot an additional insurance bill for those who have not privately insured. Consequently, the status quo in respect of insurance should remain. The more relevant question, therefore, is to what extent authorities should be liable for flooding: strictly, or only in the presence of fault?

\section{Strict liability}

A strict liability system could take numerous different forms, resulting in councils being strictly liable as soon as certain criteria are met. In terms of civil liability, this would mean that as soon as the strict liability torts are established (i.e. nuisance and Rylands as discussed above) a council could not escape liability on the basis that it had not been negligent. Such a scheme would be by no means the first of its kind in New Zealand. For example the Maritime Transport Act 1994 imposes strict civil liability on ship owners for marine pollution discharged or which has otherwise escaped from their ships. ${ }^{143}$ A strict statutory liability model may also allow for the addition of a non-delegable duty in respect of flood works. This would have the benefit that a plaintiff would be able to recover against a council even where a contractor is insolvent. In respect of flooding, this model would have to be effected through legislation as the current system already

142 The Woodhouse Report, above n 136, at [1].

143 Part 25. There are specific defences to liability under s 348. 
excludes strict liability in certain circumstances, ${ }^{144}$ the courts having limited scope to extend liability.

\section{$3 \quad$ Fault based liability}

A fault based liability system, in contrast, would hold an authority liable only in circumstances where the relevant harm was caused by its negligence. Authorities would essentially be immune from actions in respect of flood damage under the torts of nuisance and Rylands. This model, also, would require statutory reform as it is clear from and consistent with the case law to maintain the strict liability torts in appropriate circumstances. New Zealand's 'defective building' line of cases offers precedent for the courts passing on potentially widespread costs to local authorities in relation to damage to both residential and commercial buildings under a negligence standard. While these cases deal with whether a duty of care is owed (which has been demonstrated here in respect of flood works) the cases provide a useful insight into how the courts deal with issues of loss spreading in relation to local authorities.

In Sunset Terraces the Supreme Court was asked to determine whether a territorial authority owed a duty of care to a building owner in carrying out its statutory responsibilities of inspection and approval of construction for residential purposes. ${ }^{145}$ A finding against the Council would result in councils potentially paying significant sums to remedy the so-called 'leaky building syndrome'. The Court found that such a duty existed. Then, in

Spencer on Byron, ${ }^{146}$ the Supreme Court considered whether that duty might extend to the owners of buildings not for wholly residential purposes. Again, the majority held that such a duty existed. ${ }^{147}$ In that case, the issue was raised that a finding in favour of the plaintiff building owner would have the result of passing potentially large losses on to rate payers.

\footnotetext{
$144 \quad$ For example, s 148(1) of the Soil Conversation and Rivers Control Act 1941. $145 \quad$ North Shore City council v Body Corporate 188529 [2010] NZSC 158, [2011] 2 NZLR 289 (Sunset Terraces).

146 Body Corporate No 207624 v North Shore City Council [2012] NZSC 83, [2013] 2 NZLR 297 (Spencer on Byron).

147 See generally Rosmary Tobin "Leaky commercial buildings and council liability" (2012) 10 NZLJ 333.
} 
Chambers J, writing for himself and McGrath J, held that these concerns were overstated. Firstly, while recognising that we do not (or did not at the time) know the figures involved, the loss would not be passed on to ratepayers but instead to the council. ${ }^{148}$ That cost would then met through fees charged for inspection, and liability insurance if available, rates being a last resort. While that may be true in respect of building inspection there is no separate source of income available to councils in respect of protecting against floods. However, in Easton Agriculture the council, through targeted rating, gathered funds specifically from land owners who were to benefit from the protection. ${ }^{149}$ Nevertheless, the public at large are not directly charged for the building of flood works in the sense that anyone who wishes to have a building constructed must pay for the relevant inspections. Consequently, the cost of flood protection primarily comes from taxes such as rates, rather than fees charged for the construction of works.

Chambers $\mathrm{J}$ also stated that often councils will be sharing the bill of remedying defects with those involved in the construction process, while acknowledging that in "some cases" those other parties may have gone bankrupt or into liquidation. ${ }^{150}$ Whether this applies in respect of flood works depends on whether a council outsources work to contractors (who may share liability) or undertakes the work itself (leaving the council solely liable).

A purely fault based liability model would have the disadvantage that claims in the absence of any negligence which would have constituted meritorious claims between private parties under strict liability torts will not be available because they are brought in respect of a public entity. However, in the absence of specific immunity provisions liability in negligence is wholly consistent with the statutory scheme as discussed above.

In conclusion, the individual liability model while more economically efficient may be unduly harsh on those who cannot afford to insure themselves. Alternatively, a council liability model, while resulting in a

\footnotetext{
$148 \quad$ Spencer on Byron, above n 146, at [203].

149 Easton Agriculture Ltd v Manawatu-Wanganui Regional Council, above n 76.

150 At [204].
} 
complex chain of cost distributions, would have the benefit of ensuring that more homeowners are protected against loss, but at a greater financial cost to the community, depending on the extent of that liability (i.e. strict or fault based). Council liability would also benefit both the insurance industry and homeowners. Insurance companies would potentially be able to recover, and homeowners would have decreased rates of private insurance. On balance, which is preferable will turn on whether the moral value of protecting flood prone homeowners against loss outweighs the increased financial burden on the community as a whole. Ultimately, the distinction between the two models is artificial: both homeowners and councils will insure, the total loss being spread across the community in either instance. However, significantly changing the degree to which councils are liable would be for the legislature. The preferable approach is an amalgam of both the individual and council liability models: homeowners, where possible ought to have insurance, but councils should remain liable, at the very least where they have been negligent. Strict liability may, however, be overly onerous on councils during catastrophic flooding events.

\section{Conclusion}

Flooding is a significant problem in New Zealand. Its cost is surpassed only by the recent Canterbury earthquakes. Councils and communities have a real interest in protecting against flooding as best they can, but some of these measures will eventually fail, either because natural forces exceed the limits of the works, or because of problems with the protections themselves.

This essay demonstrates that councils can be liable for flooding damage in respect of their own torts, but that a non-delegable duty is not owed to general members of the public. This may have the effect that where a property is uninsured and the contractor who did the work leading to the damage is insolvent, the property owner cannot recover. The extent to which councils should be liable ultimately falls to whether the moral obligation of socialising loss outweighs acknowledging individual responsibility to insure one's own assets. In the author's view, while councils should remain liable at least for harm caused by their negligence, it would be more economically 
effective for individuals to remain responsible for protecting their assets through private insurance policies. 
V Bibliography

A Cases

$1 \quad$ New Zealand

Atlas Properties Ltd v Kapiti Coast District Council CA30/02, 20 June 2002.

Atlas Properties Ltd v Kapiti Coast District Council HC Wellington CP172/00 19, December 2001.

Black v Christchurch Finance Co Ltd [1894] AC 48, (1893) NZPCC 448.

Body Corporate No 207624 v North Shore City Council [2012] NZSC 83, [2013] 2 NZLR 297 (Spencer on Byron).

Cashfield House Ltd v David \& Heather Sinclair Ltd [1995] 1 NZLR 452 (HC).

Couch v Attorney-General [2008] NZSC 45, [2008] 3 NZLR 725 [No 1].

Davis v Lethbridge [1976] 1 NZLR 689 (SC) at 697.

Easton Agriculture Ltd v Manawatu-Wanganui Regional Council [2012] 1 NZLR 120 (HC).

Easton Agriculture Ltd v Manawatu-Wanganui Regional Council [2013] NZCA 79 (26 March 2013).

Gazley v Lower Hutt City Council HC Wellington CP 460-90, 1 April.

Green v Hamilton City Council DC Hamilton NP 921/98, 2 March 2000.

Hamilton v Papakura District Council [2000] 1 NZLR 265 (CA).

Hill v Waimea County Council HC Nelson A8/84, 12 March 1987.

Irvine \& Co Ltd v Dunedin City Corporation [1939] NZLR 741.

Landon v Rutherford [1951] NZLR 975 (HC).

Manawatu-Wanganui Regional Council [2013] NZCA 79 (26 March 2013).

Mt Albert Borough Council v Johnson [1979] 2 NZLR 234 (CA).

North Shore City council v Body Corporate 188529 [2010] NZSC 158, [2011] 2 NZLR 289 (Sunset Terraces). 
Powrie v Nelson City Corporation p1976] 2 NZLR 247.

S v Attorney-General [2003] NZCA 149, [2003] 3 NZLR 450.

Simpson v Attorney-General [1959] NZLR 546 (SC).

2 Australia

Burnie Port Authority v General Jones Pty Ltd (1994) 179 CLR 520 (HCA).

Commonwealth v Introvigne (1982) 150 CLR 258 (HCA).

Kondis v State Transport Authority (1984) 154 CLR 672 (HCA).

New South Wales v Lepore (2003) 212 CLR 511 (HCA).

$3 \quad$ England and Wales

A (Child) v Ministry of Defence [2005] QB 183.

Anns v Merton London Borough Council [1978] AC 728 (HL).

Cambridge Water Co Ltd v Eastern Counties Leather plc [1994] 2 AC 264 (HL).

Cassidy v Ministry of Health [1951] 2 KB 343.

Charing Cross Electricity Supply Co Ltd v Hydraulic Power Co [1914] 3 KB 772 (CA).

Gold v Essex County Council [1942] 2 KB 293.

Goldman v Hargrave [1967] 1 AC 645 (PC).

Greenock Corporation v Caledonian Rail Co [1917] AC 556 (HL).

Halsey v Esso Petroleum Co Ltd [1961] 1 WLR 683 (QB).

Hiap v Lee (Cheong Leong and Sons) Brickmakers Ltd v Weng Lok Mining Co Ltd [1974] 2 MLJ 1 (PC).

Honeywill and Stein Ltd $v$ Larkin Brothers (London's Commercial Photographers Ltd) [1934] 1 KB 191 (CA).

Leaky v National Trust [1980] QB 485 (CA).

McDermid v Nash Dredging and Reclamation Co Ltd [1987] AC 906 (HL). 
Midwood \& Co Ltd v Mayor, Alderman and Citizens of Manchester [1905]

2 KB 597.

Pemberton v Bright [1960] 1 WLR 436 (CA).

Rylands v Fletcher (1868) LR 3 HL 330.

Sedleigh-Denfield v O’Callaghan [1940] AC 880, [1940] All ER 349 (HL).

Spicer v Smee [1946] 1 All ER 489 (KB);

St Helen's Smelting v Tipping (1865) 11 HLC 642, 11 ER 1483 (HL) at 1486.

Wilsons \& Clyde Coal Co Ltd v English [1938] AC 57 (HL).

Woodland v Swimming Teacher Association, [2013] UKSC 66, [2014] AC 537 at 1237.

X (Minors) v Bedfordshire County Council [1995] 2 AC 633 (HL).

\section{B Legislation}

$1 \quad$ New Zealand

Accident Compensation Act 2001.

Building Act 2004.

Civil Defence Emergency Management Act 2002.

Earthquake Commission Act 1993.

Environment Act 1986.

Judicature Act 1908.

Land Drainage Act 1908.

Local Government Act 1974.

Local Government Act 2002.

Maritime Transport Act 1994.

Public Works Act 1981.

Resource Management Act 1991.

Rivers Board Act 1908. 
Soil Conservation and Rivers Control Act 1941.

Local Government Reorganisation Order 1989.

National Civil Defence Emergency Management Plan Order 2005.

\section{Books and Chapters in Books}

Michael Faure Tort Law and Economics (Edward Elgar, Cheltenham (UK), 2009) vol 1.

Tsachi Keren-Paz Torts, Egalitarianism and Distribute Justice (Ashgate, Burlington (USA), 2007).

Christopher Mitchell and Dean Knight Local Government Law in Practice (LexisNexis, Wellington, 2011).

Kenneth Palmer Local Authorities Law in New Zealand (Brookers, Wellington, 2012).

Stephen Todd The Law of Torts in New Zealand (6th ed, Brookers, Wellington, 2013).

\section{Journal Articles}

Richard Gaskins “Recalling the Future of ACC” (2000) 31 VUWLR 215.

Rosmary Tobin "Leaky commercial buildings and council liability” (2012) 10 NZLJ 333.

\section{E Reports}

John McSweeny Overview of Flood Management Legislation in New Zealand (Ministry for the Environment, November 2006).

New Zealand Royal Commission of Enquiry into Compensation for Personal Injury Compensation for Personal Injury in New Zealand: Report of the Royal Commission of Inquiry (Government Printer, Wellington, 1967) (The Woodhouse Report).

Ministry for the Environment Meeting the Challenges of Future Flooding in New Zealand (Ministry for the Environment and the Flood Risk Management and River Control Review Steering Group, August 2008). 
Mark Walton and others Economic impacts on New Zealand of climate change-related extreme events: Focus on freshwater floods (New Zealand Institute of Economic Research, July 2004).

\section{F Internet Materials}

Greater Wellington Regional Council (“Stopbanks and flood ways” (2014) Greater Wellington Regional Council < www.gw.govt.nz/Stopbanks-andflood-ways $>$ ).

LAPP “About LAPP: Background \& History” (2013) LAPP: Local Authority Protection Programme <www.lappfund.co.nz>.

Eileen McSaveney "Floods: 2004 floods” (21 February 2013) Te Ara: The Encyclopedia of New Zealand <www.teara.govt.nz/en/floods>.

The Press "Disputes over insurance payout" (8 May 2014) Stuff $<$ www.stuff.co.nz/national/10020889>.

The Press "Widower suffers ninth flood since quakes" (29 April 2014) Stuff $<$ www.stuff.co.nz/national/9989139>.

University of Canterbury "Christchurch experiences more floods” (5 March 2014) University of Canterbury: Communications

$<$ http://www.comsdev.canterbury.ac.nz/rss/news/?feed=news\&articleId=12 $27>$.

\section{G Seminars}

Andrew Butler, Dean Knight and Geoff McLay "Liability of Local Authorities” (paper presented to the New Zealand Law Society, Wellington, June 2005).

\section{$\mathrm{H} \quad$ Interviews}

Interview with ICNZ representative, Senior Representative (Sean Brennan, The Insurance Industry and Flooding, 8 August 2014).

\section{Emails}

Email from Terry Jordan (Operations Manager for the Insurance Council of New Zealand) to Sean Brennan regarding the percentage of homeowners with insurance cover for flooding (30 June 2014). 


\section{J Newspaper Articles}

Lynley Bilby “Torrential rain causes slips and power cuts" The New Zealand Herald (online ed, Auckland, 20 July 2014).

Word count: the text of this paper (excluding the abstract, footnotes, and bibliography) comprises exactly 7988 words. 